\title{
REDD+ achievements and challenges in Brazil Perceptions over time (2015-2019)
}

\author{
Patrícia Gallo ${ }^{1,2}$, Alice Brites ${ }^{3}$ and Tatiane Micheletti ${ }^{4}$
}

\section{Key messages}

- This Infobrief examines and discusses REDD+ achievements and challenges in Brazil for the period 2015-2019, reflecting the opinions of relevant actors within the REDD+ policy domain in the country.

- Over time, REDD+ initiatives have promoted changes in Brazilian political articulation, funding possibilities and mobilization of civil society, and brought more visibility to the importance of combating deforestation and forest degradation within the country.

- In terms of practical implementation, the national REDD+ framework is still quite limited.

- Further development of the national REDD+ strategy is a considerable challenge for Brazil, as it is becoming clearer that the current national political rhetoric does not consider fighting and controlling deforestation and climate change as government priorities.

- Several major challenges exist because weak forest resource governance, poor enforcement of the environmental legislation, social inequalities, land use conflicts, and lack of political commitment remain in the country's profile. However, international pressure on Brazil to stop deforestation might provide an opportunity for those actors who until now had little presence in the REDD+ political arena.

\section{Introduction}

Recent findings indicate that reducing deforestation and degradation has the potential to remove up to 5.8 billion tons of $\mathrm{CO}_{2}$ from global emissions per year (IPCC 2019). Within this scenario, Brazil has an important role. The country has almost 456 million ha of the world's remaining rainforests (SFB 2013), and despite some considerable achievements in reducing deforestation (PRODES 2012), it continues to lose rainforest areas at a very fast pace (PRODES 2019). To give countries the incentive to protect forests, different mechanisms have been discussed. Although the Paris Agreement has adopted the Reducing Emissions from Deforestation and Forest Degradation (REDD+) mechanism, overall progress has been much slower than expected (Brockhaus et al. 2015; Duchelle et al. 2018; Korhonen-Kurki et al. 2019). Despite this, REDD+ developments have contributed to valuable lessons on how to achieve forest governance and livelihood enhancement goals and have highlighted technical measures to safeguard forests (Angelsen et al. 2018). As the design of national REDD+ strategies involve different stakeholders, REDD+ also deals with the complexity of changing human behavior toward achieving sustainable land use measures (Lima 2014, 2017).
Within this context, CIFOR has been implementing the Global Comparative Study on REDD+ (GCS REDD+) since 2009. In this Infobrief, we investigate how actors have perceived REDD+ over time, comparing respondents' opinions on achievements and challenges about REDD+ policy developments in Brazil between 2015 and 2019. Understanding and exploring stakeholders' perceptions and opinions about REDD+ can provide useful insights that can guide policymakers when choosing specific interventions. Data were collected at two time points: i) between July 2015 and August 2016, and ii) from March to August 2019. In both periods, we applied two different questionnaires to the same respondents, one structured, and the other an in-depth interview with openended questions. In 2015/2016, 72 organizations participated in the research and answered the structured questionnaire, and 68 respondents took part in the in-depth interviews. In 2019, 59 organizations participated in the research: 58 respondents answered the structured questionnaire and 55 respondents answered the open-ended questions. Moreover, from the 59 organizations, 34 participated in both periods (2015/2016 and 2019) of data collection. Respondents were representatives of organizations directly or indirectly involved in the REDD+ political domain in the country, as for example government 
institutions, civil society organizations (CSOs), nongovernment organizations (NGOs), research institutions, donor organizations, business organizations and local associations, including organizations that were critical of and/or opposed to REDD+.

\section{Evolution of REDD+ in Brazil}

Deforestation and climate change are two inseparable issues in Brazil. Together, deforestation and land use change account for $70 \%$ of the total greenhouse gas (GHG) emitted by Brazil (MCTI 2016). For this reason, the main Brazilian proposal to reduce its carbon emissions revolves around halting deforestation. For instance, in its Nationally Determined Contribution (NDC) to the Paris Agreement, Brazil committed to reduce forest loss by $80 \%$ in the Amazon region and by $40 \%$ in the Cerrado areas. Following the implementation of an interministerial plan launched in 2004, the country was able to reduce its forest cover clearance in the Amazon region by $84 \%$ between 2004 and 2012 (in 2012, deforested areas covered around $4571 \mathrm{~km}^{2}$ ). However, the rate has since risen again.

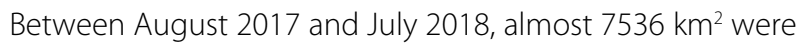
deforested (PRODES 2018). This result indicates an increase of 8.5\% compared with 2017, when $6947 \mathrm{~km}^{2}$ were registered as deforested areas. In 2019, about $9762 \mathrm{~km}^{2}$ of rainforest were lost (PRODES 2019). For 2020, there is a concern that deforestation may increase to over $11,000 \mathrm{~km}^{2}$

Brazil was one of the first countries to advocate for financial reward for avoided carbon emissions through the decrease in deforestation rates (Santili et al. 2005). At that time, however, the government often questioned how effectively and ably a mechanism such as REDD+ would be in addressing the critical issues of market pressure, property rights and sovereignty (Gil 2010). Moreover, the government has remained averse about the use of carbon credits (offset) obtained through REDD+ and claimed by developed nations under the United Nations Framework Convention on Climate Change (UNFCCC) umbrella to achieve emissions reduction targets. For example, Article 6 of the Brazilian national strategy on REDD+ (namely ENREDD+) states that originating carbon credits from REDD+ initiatives for offsetting are not allowed. Fairness has been the government's foremost concern (Lima 2017), as the same has declared that offsetting would not stimulate the duty of developed countries in applying the principle of common but differentiated responsibilities. Nevertheless, after the first positive results in fighting deforestation and considering that reducing deforestation would contribute to reducing carbon emissions, there was an increase in government support for REDD+ policies.

In 2010, a debate started at different levels of government, and then among NGOs, CSOs, the private sector and social movements regarding a national REDD+ strategy. In 2015, the National Commission on REDD+ (CONAREDD+) was established, and it also launched the ENREDD+. Moreover, REDD+ was included in Brazil's NDC to the UNFCCC. The ENREDD+ strategically aims to contribute to mitigating carbon emissions through measures against illegal deforestation, by conserving and restoring ecosystems, and by promoting socioeconomic and environmental benefits (MMA 2016). The ENREDD+ was developed based on three pillars: (i) coordination of public policies for climate change, biodiversity and forests, including safeguards; (ii) monitoring, reporting and verification (MRV) of results; and (iii) collection and distribution of payment of funds for REDD+ results (MMA 2016). The National Policy on Climate Change (NPCC) and the 2012 Forest Code are the umbrella framework for the establishment of the first pillar in the scope of the ENREDD+ implementation. In addition, three targetoriented plans were identified to promote the integration of cross-cutting measures: i) the Action Plan to Prevent and Control Deforestation in the Amazon (PPCDAm), ii) the Action Plan to Prevent and Control Deforestation and Fire in the Brazilian Cerrado (PPCerrado), and iii) the Plan for Low Carbon Agriculture (ABC). However, it also identified few opportunities for aligning, promoting and establishing synergies using such measures and REDD+ developments in Brazil (Gallo and Albrecht 2019).

Despite the valuable performance of those fighting deforestation, ever since the mandates of the administrations of ex-Presidents Dilma Rousseff (2010-2014/2014-2016) and Michel Temer (2016-2018) through to that of current President Bolsonaro, a narrative of growth-seeking as the prevailing rhetoric of economic policy strategies has justified reducing protected areas and allowing licensing activities that have a strong negative environmental impact on indigenous territories and public forests (Lima 2017). Climate change is also an overly sensitive topic for the government of Jair Bolsonaro (Escobar 2019). Bolsonaro threatened to pull Brazil out of the Paris Agreement, but pressured by the agribusiness sector, which feared its exports would be constrained, he refrained from doing so. Among Jair Bolsonaro's electoral promises was the end of environmental fines, the reduction of protected areas and a blacklisting of environmental NGOs. In a live broadcast on social networks on the night of the primaries, he promised to "put an end to all activism in Brazil" and "stop the state from impeding the rural producer". In practice, the speech was seen as a 'free pass' for clearing forested areas. As elected president, Bolsonaro promoted a reform of the federal governmental structure and dismissed some of the Ministry of Environment's (MMA) duties. Effectively, the environmental agenda of the MMA no longer has in its structure specific divisions focused on the control and prevention of deforestation and climate change, including the REDD+ institutional framework. These two topics, until then central to the MMA's performance, have been gradually disappearing and their ideas have been dismissed and ignored. 


\section{Respondents' perceptions of REDD+ achievements in Brazil}

In both periods, respondents were asked if they believed that REDD+ could bring positive changes to Brazil, and if so, what these changes were. Through a content analysis of in-depth interviews, the results showed that over time, the opinion of the actors remained consistent in certain aspects. For example, while in 2015/2016, 48.5\% of respondents said that they believed that REDD+ could bring positive changes to Brazil, in 2019,43.6\% believed that REDD+ actually had brought positive changes to Brazil. Table 1 shows the most cited and repeated achievements by the respondents in both 2015/2016 and 2019.

The results also suggest an interesting perspective. Amongst achievements perceived by the respondents, for just two achievements - i.e. that REDD+ is an essential source of financial resources enabling conservation and that REDD+ improves forest governance - has the number of actors that selected these achievements gradually increased. This also means that over time fewer actors have a positive attitude toward REDD+ in Brazil, even though respondents assumed that REDD+ actions can/could achieve such goals. Also, it is curious that in 2015/2016 only $4.2 \%$ and in 2019 - even fewer - only $3.6 \%$ of the respondents believed that REDD+ effectively reduces GHG emissions, which is the core objective of REDD+.

REDD+ as an essential source of financial resources enabling conservation. Most of the respondents believed that REDD+ has created a key new source of financial flow for conservation in Brazil. The example of the Amazon Fund was often repeated by the respondents as a positive achievement.

Table 1. Responses to REDD+ achievements in Brazil

\begin{tabular}{lcc}
\hline REDD+ Achievements & $\begin{array}{c}2015 / 2016 \\
\%(\mathrm{~N}=68)\end{array}$ & $\begin{array}{c}2019 \\
\%(\mathrm{~N}=55)\end{array}$ \\
\hline $\begin{array}{l}\text { REDD+ is an essential source } \\
\text { of financial resources enabling } \\
\text { conservation }\end{array}$ & 26.4 & 32.7 \\
\hline $\begin{array}{l}\text { REDD+ developments promote a } \\
\text { low-carbon economic model }\end{array}$ & 22 & 11 \\
\hline $\begin{array}{l}\text { REDD+ promotes the decrease in } \\
\text { deforestation rates }\end{array}$ & 21.4 & 11 \\
\hline $\begin{array}{l}\text { REDD+ actions increase the value } \\
\text { of standing forests }\end{array}$ & 18 & 14.5 \\
\hline $\begin{array}{l}\text { REDD+ fosters sustainable } \\
\text { management }\end{array}$ & 13 & 3.6 \\
\hline $\begin{array}{l}\text { REDD+ improves forest governance } \\
\text { REDD+ effectively reduces GHG } \\
\text { emissions }\end{array}$ & 4.8 & 3.6 \\
\hline
\end{tabular}

Source: Own results
Between 2008 and 2019, Norway was the major donor to the Amazon Fund, followed by Germany and Petrobras (Brazil's state oil company). Within this period, the Amazon Fund received more than USD 1.2 billion in donations, and allocated USD 667.3 million for financing 96 approved projects and initiatives (Correa et al. 2019). In August 2018, the MMA together with the United Nations Development Program (UNDP) submitted a proposal to receive funding provided by the pilot program for REDD+ results-based payments from the Green Climate Fund (GCF). The discussion was halfway through and in 2019, in addition to the process of dismantling environmental policy and legal frameworks, the CONAREDD+ was dismissed; despite this, the GCF approved the payment of USD 96 million for about 19 tons of carbon emission reductions achieved between 2014 and 2015. Because of this approval and after international pressure, the government reestablished the CONAREDD+ in November 2019, precisely before the COP25 held in Madrid. The financial resource from the GCF should be used to launch a program called Floresta+ aimed at the protection of environmental services, ecosystem restoration, and strengthening the governance framework of the ENREDD+ (MMA 2018). Floresta+ should also be aligned with the approaches already undertaken in the ENREDD+. However, although in the Brazilian context, the Amazon Fund established the REDD+ mechanism as a genuine approach for achieving international cooperation and resources (Ortiz 2018), the current government unilaterally dismissed the Amazon Fund's Steering Committee and suspended its activities from August 2019. The government claimed alleged irregularities in the Amazon Fund's resources spending by NGOs. The government has not yet proved such irregularities. In response, contributions to the fund coming from the Norwegian and German governments have been suspended, under the allegation that the Brazilian government broke the rules of the agreement, since Brazil announced an overhaul of the Amazon Fund's administrative system. Nevertheless, some Amazonian states are independently planning on negotiating an alternative to the Amazon Fund with Norway and Germany. In addition, further development is needed, but it is unclear which measures and approaches the federal government will establish.

\section{REDD+ as an instrument for improving forest}

governance. The Brazilian REDD+ political development concretely started as the government created the NPCC and established measures to reduce deforestation. Most actors believe that REDD+ offers a governance framework to enable politicians in Brazil to reduce deforestation and contribute to climate change mitigation. Respondents also believed that REDD+ would promote, in the national context, not only changes in the political articulation among federal government, state government and public environmental institutions, especially in the Amazon region, but also the mobilization of civil society and vulnerable groups that had begun to have a stronger discourse in relation to the conservation potential of the forest aligned with an economic 
agenda. Moreover, REDD+ developments in Brazil bring more visibility to the importance of fighting deforestation and forest degradation, and discussions about rights, empowerment and social inequalities. Furthermore, in the opinion of the actors on the ground, Brazil shows several examples of fruitful REDD+ actions that created an enabling environment for the integration of efforts within levels and sectors. REDD+ has been previously positively recognized at sub-national levels rather than at the federal level in the country. At the jurisdictional level, state governments such as those from Amazonas, Mato Grosso, Acre and Pará, and now Tocantins and Rondônia, played and play proactive roles in the Brazilian REDD+ domain. For example, the states of Mato Grosso and Acre are involved in the context of the REDD+ for Early Movers (REM) Program. In 2018, the state of Acre was in its second phase of the program, while Mato Grosso was in the initial phase of planning and implementation of the REM program. Moreover, the state of Acre has also negotiated and signed a memorandum of understanding (MoU) with the state of California as part of the Governors Climate and Forests task force to take part in its cap and trade market. Since 2018, the government of Tocantins has been working on implementing a jurisdictional REDD+ program, which aims to build the jurisdictional program throughout the state. Lastly, at project level, several examples exist in Brazil. The first REDD+ project implemented in 2006 in the Amazon region was the Juma project, which is incorporated into the Bolsa Floresta Program scope, an initiative that pays forest communities to maintain their primary forests within conservation units in the state of Amazonas.

\section{Challenges for REDD+ in Brazil}

Analysis of the structured questionnaires shows that results are quite similar over time. In general, respondents tended to agree that all the topics presented are considered challenges in the national REDD+ political arena. However, results also indicate that in 2019, the respondents expressed a higher level of agreement toward most statements than in 2015/2016. This might reflect the current political situation in Brazil, especially concerning environmental issues. Despite the favorable international scenario, Brazil's role as an important partner in international pro-climate negotiations has reduced over recent years. The country has not been promoting environmental innovation nor transforming the South-South cooperation initiatives (Viola and Gonçalves 2019). Nationally, this might suggest that such achievements are ephemeral, and previous challenges such as increased deforestation rates, social inequalities and impunity against environmental crimes remain or have possibly worsened. Respondents were asked about their level of agreement with the following stances, presented in the structured questionnaire. Table 2 presents respondents' views on challenges for REDD+ implementation in Brazil, including the percentages of how many of the respondents agreed with the statements.
Table 2. Stakeholders' perceptions on challenges for REDD+ in Brazil

\begin{tabular}{|c|c|c|}
\hline $\begin{array}{l}\text { One of the main challenges for the } \\
\text { ENREDD+ implementation is ... }\end{array}$ & $\begin{array}{c}2015 / 2016 \\
\%(N=72)\end{array}$ & $\begin{array}{c}2019 \\
\%(N=58)\end{array}$ \\
\hline $\begin{array}{l}\text {... lack of knowledge and } \\
\text { awareness about REDD+ by relevant } \\
\text { stakeholders }\end{array}$ & 74 & 85 \\
\hline $\begin{array}{l}\text {... achieving effective coordination } \\
\text { between state agencies, the private } \\
\text { sector and civil society }\end{array}$ & 89 & 98 \\
\hline $\begin{array}{l}\ldots \text { the lack of technical expertise } \\
\text { for monitoring carbon emissions } \\
\text { and sequestration }\end{array}$ & 51 & 40 \\
\hline $\begin{array}{l}\ldots \text { the effective clarification of } \\
\text { tenure rights }\end{array}$ & 81 & 89 \\
\hline $\begin{array}{l}\text {... contradictions among laws and } \\
\text { regulations in forestry, agriculture } \\
\text { and other sectors }\end{array}$ & 75 & 98 \\
\hline $\begin{array}{l}\text {... contradictions among laws and } \\
\text { regulations at different jurisdictional } \\
\text { levels (e.g. between national and } \\
\text { subnational levels) }\end{array}$ & 73 & 93 \\
\hline ... social conflict and local resistance & 65 & 76 \\
\hline $\begin{array}{l}\text {... effectively addressing the main } \\
\text { drivers of deforestation without } \\
\text { compromising development } \\
\text { objectives }\end{array}$ & 72 & 74 \\
\hline $\begin{array}{l}\ldots \text { achieving broad consensus on } \\
\text { changes in existing land use plans }\end{array}$ & 83 & 93 \\
\hline $\begin{array}{l}\text {... low capacity to enforce laws and } \\
\text { regulations }\end{array}$ & 90 & 95 \\
\hline $\begin{array}{l}\text {... negotiating with powerful } \\
\text { special interests influencing the } \\
\text { main drivers of deforestation }\end{array}$ & 82 & 91 \\
\hline ... lack of finance & 81 & 80 \\
\hline
\end{tabular}

Source: Own results

In 2014, Gebara et al. (2014) showed that a major challenge related to REDD+ in Brazil would be coordination. This means that the absence of coordination and synergies between different sectors (e.g. government, civil society and private sector) suggested that national REDD+ governance in Brazil would likely be suboptimal. Looking at Table 2, in 2019, the items: contradictions among laws and regulations at different jurisdictional levels and sectors; achieving effective coordination between state agencies, the private sector and civil society; and low capacity to enforce laws and regulations received the highest level of agreement from respondents. However, negotiating with powerful special interest groups influencing the main drivers of deforestation, achieving broad consensus on changes in existing land use plans as well as clarification of tenure rights 
continued strongly to be acknowledged as major challenges impeding an effective implementation of the ENREDD+. Government organizations occupy a strategic position in relation to the REDD+ challenges in Brazil. While other types of organizations answered more often that achieving broad consensus on changes in existing land use plans, and negotiating with powerful special interest groups were two of the most important challenges to be dealt with in Brazil, the government considered the lack of knowledge, coordination issues and clarification of tenure rights as important challenges. Among these topics, in 2019, 89\% of all respondents considered the lack of transparency around land tenure a significant issue.

Land tenure and property rights remain a controversial issue in the country. The lack of an integrated database, limitations of the land registry, the institutional complexity of the bureaucratic environment of land rights governance (quite aside from conflicts and inequality), are some examples of the challenges within this context (Costa 2016). Of the $36.1 \%$ of all land set aside as public lands, around 70 million ha are undesignated without supervision, and $16.6 \%$ are unregistered or with unknown tenure (Azevedo-Ramos and Moutinho 2018; Sparovek et al. 2019). These facts emphasize an interesting linkage to the results. In 2015/2016, 51\% of the respondents, and in 2019 only $40 \%$ of the interviewees, answered that the lack of technical expertise around monitoring carbon emissions and sequestration was a challenge for Brazil. Thus, it was recognized that in the forestry context, the measurement of carbon emissions is tied to the measurement of deforestation rates. Indeed, Brazil has a reliable and transparent forest monitoring system, and has improved substantially the carbon accounting methodology for the land-use sector (Rajão et al. 2017). This means that the monitoring systems adopted by Brazil are also accounting for carbon emissions from forest degradation and the conversion of secondary forests. Nevertheless, without a proper solution to the land tenure constraints problem in Brazil, distinguishing between legal and illegal deforestation will continue to be a major challenge for forest governance and monitoring in the country.

Considering the economic background of the Amazon region, we observe that when a forest is kept without an economic purpose integrated with conservation principles, and without the presence of indigenous people and traditional communities, this asset becomes the target of illegal exploitation (Lima 2017). Still, tenure is only one of the challenges to be resolved. Even with a secure tenure system, the users and the government still face pressures, to either respond to incentives to protect forests or to use forest resources, in order to address, for instance, national debts (Cotula and Mayers 2009; Lima 2017). The changes applied by the 2012 Forest Code brought about many uncertainties in this context, signaling that increases in deforestation rates would be tolerated in exchange for political support. With its anti-environment agenda, the current government has started the establishment of a process of lowering environmental licensing standards, suspending the ratification of indigenous lands, reducing the legal size of protected areas, and seeding the popular belief that the illegal occupation of public forestlands will be accepted as a means of development. Apart from causing direct forest damage, this also undermines Brazil's ability to reduce its carbon footprint and achieve the Paris Agreement's targets.

In addition to the results contained in Table 2, through an analysis of the in-depth interviews, it can be identified that in 2015/2016, most of the respondents strongly highlighted the participation design adopted in REDD+ negotiations as a major challenge in Brazil. Respondents claimed that the federal government has not done enough to ensure the inclusion of the major interested constituencies in policy development discussions, as it has left aside the state and municipal governments, and in many cases, local actors such as indigenous peoples and traditional communities. In 2019, also according to the in-depth interviews, other factors such as the lack of a regulatory framework for REDD+, lack of governmental priority, and again the lack of participation by different stakeholders in decision-making processes were recognized as major constraints hindering a successful implementation of the ENREDD+. Actors stated that although participation and transparency are designed into the national framework, the channels for communication and participation are considered deficient.

The struggle between the two discourses 'agriculture expansion vs. forest conservation' still dominates policy development countrywide. The legal regulatory policy domain still has its pillars based on the conflict of interests between a national legislation that fosters trade and commercialization of agricultural commodities, but also promotes exploitation of natural resources, and ignores sustainable use and conservation principles. Moreover, all such constraints seem to constantly lead to a lack of political will for seeking transformation and changes (Gallo and Albrecht 2019). Bidone and Kovacic (2018) described two overlapping but distinct types of logic in the evolution of environmental policies in Brazil. The first emphasizes economic growth and the physical opening of frontiers for the development of activities such as mining, logging and extensive agriculture. The second one recognizes the negative impacts generated by these development strategies. However, the implementation of environmental policies is not based on a process of substitution of new narratives over the existing ones, but rather on overlapped contradictions and inconsistencies between policies. This results in a re-emergence of narratives over time and in correspondence with economic and political priorities, which historically show that in Brazil, the development and progress rhetoric continuously predominates (supported by a strong political lobby) over the sustainable environmental reasoning. 
In $2019,80 \%$ of the respondents, and in 2015/2016, $81 \%$ of actors answered that the lack of finance is a challenge faced by Brazil. Ensuring finance to fund REDD+ has been controversial since the beginning of international negotiations. For instance, even though the IPCC report shows that land-oriented climate solutions could deliver more than one-third of the emission reductions needed to keep global warming below $1.5^{\circ} \mathrm{C}$, such measures received only $3 \%$ of global climate funding (Angelsen et al. 2018). REDD+ funding has been an important source of forest protection in the Amazon region, despite the fact that most of the recent funding for forest projects in the country has come from Brazil's own state and federal public funds (da Silva et al. 2017). The challenge reflects again the conflicted dichotomy 'agriculture vs. forest.' While investments in the agricultural sector have been around USD 55 billion annually, just over USD 2.2 billion have been committed to the development of REDD+ activities, and merely USD 80 million have been tracked in financial flows aimed at promoting low-carbon agriculture in the Amazon region (da Silva et al. 2017). Moreover, as the ENREDD+ does not accept offsetting and does not integrate private REDD+ initiatives under the national framework, this circumstance might not only increase disagreement between federal and state governments as Amazonian states have been working hard on bi- and multilateral funding agreements - but it may also limit international financial sources (Di Gregorio et al. 2016; Gallo and Albrecht 2019). This shows that to advance REDD+ in the country, Brazil must diversify its finance sources and seek a better alignment of private and public sector finance structure to promote integration between forest conservation activities and agricultural expansion. Moreover, it is essential for Brazil to promote a low-carbon agriculture model, as investments in this sector are still exceptionally low in comparison with traditional agriculture credit lines.

\section{REDD+ outlook}

In practical terms of implementation, the ENREDD+ framework is still very limited. It was expected that many of the current developments in Brazil would have already evolved into longterm interventions, such as monitoring and control of illegal deforestation, with an established arrangement for payment for performance at the sub-national level - considering the significant results achieved in reducing deforestation between 2004 and 2015. Nevertheless, the regulation of the ENREDD+ has barely evolved since then (da Silva et al. 2017). In the respondents' points of view, REDD+ in Brazil is seen as a financial source to enable conservation rather than as an effective tool to implement sustainable forest management. At the same time, it is controversial and difficult to analyze how much REDD+ has contributed concretely to decreasing deforestation rates in Brazil. This is because many of the measures were implemented before the establishment of ENREDD+ and because of the difficulty in defining whether an action is a REDD+ initiative or not. Through the analysis of the in-depth interviews, this distinction can be observed. Some respondents, especially those from the private sector, stated that there is a gap between the clearness of what REDD+ entails and its implementation in Brazil. Other studies indicated that, to date, the importance of REDD+ in terms of carbon measurement, scope, depth, performance and on-ground implementation has not been measured and properly evaluated (Duchelle et al. 2018; Arts et al. 2019).

Further, in 2019, we asked respondents about the future of REDD+ in the national context. On the one hand, $40 \%$ of the respondents answered "worrying/difficult to visualize/ pessimistic," 20\% said that the future is uncertain on account of the dismantling of environmental institutions that is currently happening in the federal governmental sphere, 11\% believed that many setbacks will emerge in the work done so far and 3.6\% believed that REDD+ is "dead" in Brazil. On the other hand, $20 \%$ of the interviewees had an optimistic view, saying that now is an opportunity for transformation with greater involvement of the key players. Brazil is a peculiar case in relation to the REDD+ context, since the present government is weakening all instances of negotiation in the climate context (Escobar 2018, 2019), but at the same time it just received USD 96 million from the GCF. In the short term, the further development of the ENREDD+ is a considerable challenge for Brazil, as it is becoming clearer that the current national political rhetoric does not consider fighting deforestation and climate change as governmental priorities. In the long run, however, there will clearly be stronger international pressure for Brazil to take more effective measures against deforestation due to the international tendency for countries to assume sustainable consumption levels and production processes. In this scenario, there could be an opportunity for those actors who until now had little space in the political arena.

\section{Final remarks}

In Brazil, REDD+ promoted changes in the political articulation, funding possibilities and mobilization of civil society, and brought more visibility to the importance of combating deforestation and forest degradation. However, several major challenges such as lack of political commitment, inefficient forest resource governance, insufficient enforcement of the environmental legislation, social inequalities and land use conflicts remain. REDD+ can only be effective in the national context when Brazil tackles the root causes and drivers of deforestation, which requires more than just speeches and technical responses. In this sense, there is a need to align institutional discourse with actions executed and a strong political will for generating sound regulatory frameworks. This means that Brazil needs a more coherent interpretation of the REDD+ agenda in the country, aligning the different interests from the stakeholders and the government's proposal for the national REDD+ framework. The ENREDD+ might be sufficiently broad to accommodate 
different interests. In addition, effective and complementary mechanisms for assessing carbon emission reductions from deforestation and removals related to agriculture (livestock) should be created, synergies between a low carbon economy and the valuation of forest assets should be stimulated, and the removal potential of all Brazilian biomes should be incorporated in the national framework. Equity, fairness and transparency in decision-making procedures should be ensured, and the principles of sustainable forest management should be implemented. Brazil was a pioneer in its initial efforts to reduce deforestation, and for a while, it was the best study case worldwide. However, the scenario has drastically changed, and all efforts made so far will not be sustained without political reforms and stronger commitments.

\section{Acknowledgments}

This study is a component of the Global Comparative Study on REDD+ being conducted by CIFOR (www.cifor.org/gcs). We would like to thank donors including the Norwegian Agency for Development Cooperation (NORAD), United States Agency for International Development (USAID), the German Federal Ministry for the Environment, Nature Conservation and Nuclear Safety (BMU), and the CGIAR Research Program on Forests, Trees and Agroforestry (FTA) for their financial support. We would also like to thank all interviewees for participating in this study. We greatly appreciate the support given by Isadora Ribeiro and Laize Sampaio during the field work and data collection. Moreover, we want to express our sincere gratitude to Moira Moeliono and Bimo Dwi Satrio for especially useful comments and to Pham Thu Thuy for writing support and editing.

\section{References}

Angelsen A, Martius C, De Sy V, Duchelle AE, Larson AM and Pham T, eds. 2018. Transforming REDD+: Lessons and new directions. Bogor, Indonesia: CIFOR.

Arts B, Ingram V and Brockhaus M. 2019. The performance of REDD+: From global governance to local practices. Forests 10:837; 09 pp.

Azevedo-Ramos C and Moutinho P. 2018. No man's land in the Brazilian Amazon: Could undesignated public forests slow Amazon deforestation? Land Use Policy 73:125-27.

Bidone F and Kovacic Z. 2018. From nationalism to global climate change: analysis of the historical evolution of environmental governance in the Brazilian Amazon. International Forestry Review 20(4):420-35.

Brockhaus M, Korhonen-Kurki K, Sehring J, Di Gregorio M. 2015. Policy progress with REDD+ and the promise of performance-based payments: A qualitative comparative analysis of 13 countries. Working Paper 196. Bogor, Indonesia: CIFOR.

Correa J, van der Hoff R and Rajão R. 2019. Amazon Fund 10 years later: Lessons from the world's largest REDD+ program. Forests 10:272; 20pp.
Costa R. 2016. Insecure land rights in Brazil: Consequences for rural areas and challenges for improvement. Rio de Janeiro, Brazil: Climate Policy Initiative.

Cotula L and Mayers J. 2009. Tenure in REDD: start point or afterthought? Natural Resource Issues, No. 15. London, UK: International Institute for Environment and Development. $67 \mathrm{pp}$.

da Silva A, Cenamo M and Chávez G. 2017. Mapeamento dos Fluxos Financeiros para REDD+ e Uso da Terra no Brasil: análise nacional e subnacional para período de 2009 a 2016. [In Portuguese]. Forest Trends/IDESAM Report, Brazil. pdf version, 33pp. Accessed 03 April 2020. https://idesam.org/ publicacao/Mapeamento-fluxos-REDD.pdf

Di Gregorio M, Fatorelli L, Pramova E, May, P, Locatelli B and Brockhaus M. 2016. Integrating mitigation and adaptation in climate and land use policies in Brazil: A policy document analysis. Sustainability Research Institute Paper, 94, Centre for Climate Change Economics and Policy Working Paper No. 257, CIFOR Working Paper No. 194. University of Leeds, UK. Accessed 05 April 2020. https://www.cccep.ac.uk/ wp-content/uploads/2016/02/Working-Paper-257-DiGregorio-et-al-2016.pdf

Duchelle A, Simonet G, Sunderlin W and Wunder S. 2018. What is REDD+ achieving on the ground? Current Opinion in Environmental Sustainability 32:134-40.

Escobar H. 2019. Bolsonaro's first moves have Brazilian scientists worried. Science 363(6425):330.

Escobar H. 2018. Scientists, environmentalists brace for Brazil's right turn. Science 362(6412):273-4.

Gallo P and Albrecht E. 2019. Brazil and the Paris Agreement: REDD+ as an Instrument of Brazil's Nationally Determined Contribution Compliance. International Environmental Agreements: Politics, Law and Economics Journal 19(1):123-44.

Gebara MF, Fatorelli L, May P and Zhang, S. 2014. REDD+ policy networks in Brazil: constraints and opportunities for successful policy making. Ecology and Society 19(3):53.

Gil J. 2010. Reduced Emissions from Deforestation and Forest Degradation (REDD) as a tool for Climate Change Mitigation in Brazil [Master Thesis]. Stuttgart, Germany: Universität Hohenheim, Institute of Agricultural Economics and Social Sciences in the Tropics and Sub-tropics.

[IPCC] Intergovernmental Panel on Climate Change. 2019. Summary for Policymakers of IPCC Special Report on Global Warming of $1.5^{\circ} \mathrm{C}$. Working Group I Technical Support Unit, IPCC, Switzerland.

Korhonen-Kurki K, Brockhaus M, Sehring J, Di Gregorio M, Assembe-Mvondo S, Babon A, Bekele M, Benn V, Gebara MF, Kambire H, et al. 2019. What drives policy change for REDD+? A qualitative comparative analysis of the interplay between institutional and policy arena factors. Climate Policy 19(3):315-28.

Lima PGB. 2017. Brazil in the Global Forest Governance: the Brazilian initiative of developing a national strategy on REDD+ policies [PhD Thesis]. Cottbus, Germany: BTU Cottbus-Senftenberg. 
Lima PGB. 2014. Strengthening livelihood flows on Payment for Environmental Services through local lenses: Evidences from the Bolsa Floresta Programme. Journal of Sustainable Development Studies 7(1):52-83.

[MCTI] Ministry of Science, Technology and Innovation, Secretariat of Policies and Programs of Research and Development, and General Coordination of Global Climate Change. 2016. Third National Communication of Brazil to the United Nations Framework Convention on Climate ChangeVolume III. Brasília, Brazil: MCTI. pdf version. Accessed 04 April 2020. https://unfccc.int/resource/docs/natc/branc3es.pdf

[MMA] Ministry of Environment. 2018. REDD+ results-based payments for results achieved by Brazil in the Amazon biome in 2014 and 2015. GCF Documentation Funding Proposal, pdf version.Accessed 26 April 2020. http://redd.mma.gov.br/ images/central-de-midia/pdf/Documentos/untitled.pdf [MMA] Ministry of Environment. 2016. ENREDD+ Estratégia Nacional para Redução das Emissões Provenientes do Desmatamento e da Degradação Florestal, Conservação dos Estoques de Carbono Florestal, Manejo Sustentável de Florestas e Aumento de Estoques de Carbono Florestal. Accessed 03 February 2020. http://redd.mma.gov.br/images/ publicacoes/enredd_documento_web.pdf

Ortiz F. 2018. Ten years on, Amazon Fund receives applause, criticism, faces new tests. Mongabay. Accessed 19 April 2020. https://news.mongabay.com/2018/12/ten-years-onamazon-fund-receives-applause-criticism-faces-new-tests/ [PRODES] Programa de Monitoramento da Floresta Amazônica Brasileira por Satélite. 2019. Estimativa da Taxa de Desmatamento da Amazônia em 2017-2018. Brasília,
Brazil: Ministério da Ciencia e Tecnologia. Accessed 06 April 2020. http://www.obt.inpe.br/OBT/assuntos/programas/ amazonia/prodes

[PRODES] Programa de Monitoramento da Floresta Amazônica Brasileira por Satélite. 2018. Estimativa da Taxa de Desmatamento da Amazônia em 2017-2018. Brasília, Brazil: Ministério da Ciencia e Tecnologia. Accessed 06 April 2020. http://www.obt.inpe.br/OBT/assuntos/programas/ amazonia/prodes

[PRODES] Programa de Monitoramento da Floresta Amazônica Brasileira por Satélite. 2012. Estimativa da Taxa de Desmatamento da Amazônia em 2011-2012. Brasília, Brazil: Ministério da Ciencia e Tecnologia. Accessed 06 April 2020. http://www.obt.inpe.br/OBT/assuntos/programas/ amazonia/prodesramas/amazonia/prodes

Rajão R, Moutinho P and Soares L. 2017. The rights and wrongs of Brazil's forest monitoring systems. Conservation Letters 10(4), 495-96.

Santilli M, Moutinho P, Schwartzman S, Nepstad D, Curran L and Nobre C. 2005. Tropical deforestation and the Kyoto Protocol: an editorial essay. Climate Change 71:267-76.

[SFB] Serviço Florestal Brasileiro. 2013. Brazilian forests at a glance 2013: data from 2007 to 2012. Brasília, Brazil: Ministério do Meio Ambiente (MMA).

Sparovek G, Reydon B, Pinto L, Faria V, Freitas F, AzevedoRamos C, Gardner T, Hamamura C, Rajão R, Cerignoni F, et al. 2019. Who owns Brazilian lands? Land Use Policy 87:1-3.

Viola E and Gonçalves V. 2019. Brazil ups and downs in global environmental governance in the 21 st century. Revista brasileira de política internacional 62(2):1-10.

\section{RESEARCH}

PROGRAM ON

Forests, Trees and

Agroforestry
The CGIAR Research Program on Forests, Trees and Agroforestry (FTA) is the world's largest research for development program to enhance the role of forests, trees and agroforestry in sustainable development and food security and to address climate change. CIFOR leads FTA in partnership with Bioversity International, CATIE, CIRAD, ICRAF, INBAR and TBI.

FTA's work is supported by the CGIAR Trust Fund: cgiar.org/funders/

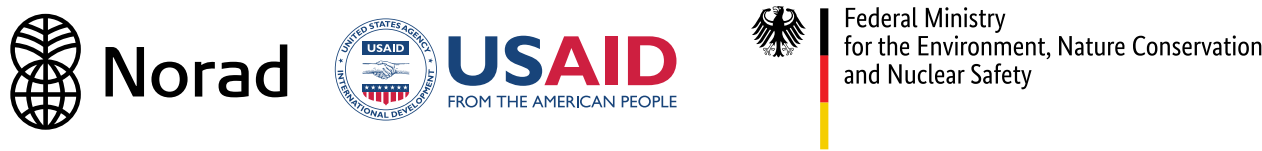

